\title{
TIESISKĀS NOTEIKTİBAS PRINCIPA IETEKMES PALIELINĀŠANAS PERSPEKTĪVAS SAVSTARPĒJĀS SASKAN̦OŠANAS PROCEDŪRĀS STARP KOMPETENTAJĀM IESTĀDĒM
}

\section{PROSPECTS FOR INCREASING THE IMPACT OF LEGAL CERTAINTY PRINCIPLE IN MUTUAL AGREEMENT PROCEDURE BETWEEN COMPETENT AUTHORITIES}

\author{
Krists Ansons, $M g$. iur.
}

\section{Summary}

Mutual agreement procedures operate in an environment that is highly unpredictable to companies. Regulatory transfer pricing changes have a disrupting effect on elimination of double taxation.

The topic is particularly relevant today, as Latvia has agreed to try to comply with OECD, BEPS Action 14 Mutual agreement procedure minimum standards, and has implemented EU Council Directive 2017/1852 of 10 October 2017 on tax dispute resolution mechanisms in the European Union.

The purpose of this paper is to analyze the prospects for increasing the impact of legal certainty principle in mutual agreement procedure between competent authorities.

The results of the work expose the problems of mutual agreement procedures in Latvia and reveal that more work remains to be done to increase legal certainty in mutual agreement procedures of Latvia.

Atslēgvārdi: savstarpējās saskaṇošanas procedūras, tiesiskā noteiktība, transfertcenas

Keywords: mutual agreement procedure, legal certainty, transfer pricing

\section{Ievads}

Savstarpējās saskaņošanas procedūras (turpmāk - arī MAP) ir viens no pārnacionālajiem sadarbības instrumentiem, kas pieejams saskaṇā ar Latvijas Republikas nodokḷu tiesībām. Autors apskatīs tēmu transfertcenu savstarpējās saskaņošanas procedūru kontekstā. 1776. gadā nodokḷu iekasēšanas politikā Ādams Smits izvirzīja četrus galvenos principus. Proporcionalitātes principu, efektivitātes, vienkāršības un paredzamības principu. ${ }^{1} \bar{A}$. Smits uzskatīja, ka

1 Smith A. An Inquiry into the Nature and Causes of the Wealth of Nations. Available at: https:// www.ibiblio.org/ml/libri/s/SmithA_WealthNations_p.pdf 639 - 641.p [aplūkots 25.03.2017.]. 
neliela neskaidrība nodokḷa maksāšanas laikā, nodokḷa iekasěšanas manierē vai maksājamajā daudzumā veicina nodokḷu iekasētāja nekaunību un korumpētību. ${ }^{2}$

Arī mūsdienās vēl joprojām aktuālas Smita atziṇas. Neskaidrība nodokḷ̂u iekasēšanas manierē rada patvalıas risku, kas ir viens no faktoriem, kurš demotivē vietējos saimnieciskās darbības veicējus, atgrūž investorus un starptautisko uzņēmumu grupas. Nodokḷu tiesību jomā ar tiesību principu piemērošanu vien nepietiek, normatīvo aktu vakuumā kompetentās iestādes var pieņemt nodokḷu maksātājiem neskaidras un nepieņemamas nostādnes.

Lìdz ar tehnologiju attīstību uzṇēmumiem un personām saimnieciskās darbības un tās palīgdarbību veikšanas vieta vairs nav tik svarīga, piemēram, ar interneta izgudrošanu apmainīties ar liela apjoma informāciju ir vienkāršāk, var arī kontrolēt starptautiskās uzņēmumu grupas saimniecisko darbību no attāluma. Vienlaicīgi ir pieaugušas personu pārvietošanās iespējas, piemēram, piekḷuve transportlīdzekḷiem, bezvīzu režīmam un ES bezrobežu teritorijai. Šie apstākḷi veicina starpvalstu nodokḷu konkurenci. Nodokḷu konkurences apstāklos valstu interesēs ir sadarboties un taisnīgi savstarpēji sadalìt nodokḷu iekasēšanas tiesības, ņemot vērā starptautisko uzṇēmumu intereses. Dubultā aplikšana ar nodokḷiem būtiski kaitē uzṇēmumiem un rada tiem zaudējumus vairāku miljonu eiro apmērā, ${ }^{3}$ tomēr jāatzīst, ka nodokḷu konvencijas var saturēt mehānismus, ko šie paši uzñēmumi var izmantot, lai izvairìtos no nodokḷ maksāšanas. ${ }^{4}$ Latvijas izpratnē dubultā aplikšana ar nodokḷiem izcel̦as tikai tad, ja nodoklis jau ir samaksāts. Dubultā aplikšana ar nodokḷiem īpaši aktuāla starptautisko uzñēmumu grupām, kas vēlas paplašināt savu darbību, dibinot saistîtus uzṇēmumus valstīs, ar kurām nav noslēgtas nodokḷu konvencijas. Divas visbiežākās strīdu jautājumu situācijas, ko var risināt savstarpējās saskaņošanas procedūru ietvaros, ir 1) situācija, kur vienā valstī uzņēmuma pel̦na ir aplikta ar uzṇēmuma ienākuma nodokli (turpmāk - UIEN) un citā valstī ar iedzīvotāju ienākuma nodokli vai UIEN ir apliktas dividendes no šìs pel̦nas, 2) situācija, kur, uzn̦ēmumam gūstot peḷnu, vienu un to pašu pel̦nu apliek ar UIEN gan viena valsts, gan kāda cita valsts. Savstarpējās saskaņošanas procedūras ietvaros var risināt arī citas starptautisko nodokḷu strīdu jautājumu lietas, piemēram, lietas par pastāvīgo pārstāvniecību izcelšanās kritērijiem.

\section{Par MAP regulējošajiem normatīvajiem aktiem un procedūras mērḳi}

Pirmais līgums par dubultās aplikšanas ar nodokḷiem novēršanu tika slēgts 1872. gadā starp Lielbritāniju un Šveici par mantojuma nodevām. ${ }^{5}$ Vēsturiski dubultās aplikšanas novēršanas risinājumus globālā līmenī sāka attīstìt

2 Smith A. An Inquiry into the Nature and Causes of the Wealth of Nations. Available at: https://www. ibiblio.org/ml/libri/s/SmithA_WealthNations_p.pdf 639 - 641.p [aplūkots 25.03.2017.].

3 b.a. Double taxation pact put on ice as businesses cry foul. Available at: https://www.theeastafrican. co.ke/business/Double-taxation-pact-put-on-ice-as-businesses-cry-foul-/2560-3897322-2yfij/index. html [aplūkots 05.01.2020.].

4 b.a. Dutch double taxation treaties lead to huge revenue losses in developing countries. Available at: https://www.somo.nl/dutch-double-taxation-treaties-lead-to-huge-revenue-losses-in-developingcountries/ [aplūkots 06.01.2020.].

5 Jogarajan S. The Conclusion and Termination of the 'First' Double Taxation Treaty (October 1, 2012). British Tax Review, Vol. 3, 2012; University of Melbourne Legal Studies Research Paper, No. 604. Available at: https://ssrn.com/abstract=2154760 [aplūkots 06.01.2020.]. 
20. gadsimta sākumā. Pirmā starptautiskā organizācija, kas periodiski sāka attīstīt konvencijas modeli par dubultās aplikšanas ar nodokḷiem novēršanu, bija Tautu Savienība, kas pirmo konvencijas modeli sagatavoja 1926. gadā. ${ }^{6}$ Tautu Savienība konvencijas modelī 1928. gadā iestrādāja pirmo koncepciju strīdu risināšanas mehānismiem, kas paredzēja, ka valstis var savā starpā vienoties par nodokḷu konvencijas normu interpretāciju un piemērošanu un uzsākt MAP. ${ }^{7}$ Tautu Savienības darbu pie MAP koncepcijas turpināja Eiropas Ekonomiskās sadarbības organizācija ${ }^{8}$ (OEEC), kas 1961. gadā kḷuva par Ekonomiskās sadarbības un attīstības organizāciju (OECD). ${ }^{9}$ Pašreiz savstarpējās saskaṇošanas procedūras juridiskais pamats starptautiski izriet no OECD un ANO parauga balstītām starp valstīm slēgtajām nodokḷu konvencijām par nodokḷu dubultās uzlikšanas un nodokḷu nemaksāšanas novēršanu (turpmāk - nodokḷu konvencijas). Daḷu no šīm konvencijām, sākot ar 2019. gadu, modificē "Daudzpusējās konvencijas nodokḷu bāzes samazināšanas un peḷnas novirzišanas novēršanas pasākumu ieviešanai attiecībā uz nodokḷu konvencijām” (turpmāk - MLI). Eiropas Savienībai ir savi normatīvie akti, kas regulē MAP kopā ar nodokḷu konvencijām un MLI: Konvencija par nodokl̦u dubultās uzlikšanas novēršanu sakarā ar asocièto uzṇēmumu peḷnas korekciju (turpmāk - arī arbitrāžas konvencija), kā arī ES direktīva (ES) 2017/1852 par nodokḷu strīdu izšķiršanas mehānismiem. Latvija nesen pārṇēma ES direktīvu (ES) 2017/1852 Likumā par nodokḷiem un nodevām. Šì direktīva ir piemērojama visās ES valstīs kopš 2019. gada 1. jūlija par dubultās aplikšanas ar nodokḷiem u. c. strīdus jautājumiem saistībā ar ienākumiem, kas gūti pēc 2018. gada 1. janvāra (ieskaitot). Latvija ir noslēgusi nodokḷu konvencijas ar visām ES dalïbvalstīm, Latvijas nodokḷu konvenciju kopskaits ir 61, kas kopā aptver 62 jurisdikcijas. ${ }^{10}$ Citu normatīvo aktu, kas paredzētu MAP, nav, līdz ar to Latvijas nodokḷu maksātājiem jārēḳinās, ka MAP var slēgt tikai ar šìm 62 jurisdikcijām, pārējos MAP iesniegumus par dubultās aplikšanas ar nodokḷiem novēršanu neizskatīs. MAP regulējums katras noslēgtās konvencijas ietvarā var būtiski atšksirties, lìdz ar to MAP procedūrai ar katru jurisdikciju var piemērot unikālu pieeju. Visas MAP procedūras vieno nodokḷu konvenciju galvenais mērḳis, dubultās nodokḷu aplikšanas novēršana. ${ }^{11}$ MAP procedūras ietvaros Latvijā izšķir transfertcenu, nodokḷu rezidences, ieturējuma nodokḷu un citus strīdus starp valstīm, kuri rodas, interpretējot un piemērojot nodokḷu nolīgumus un konvencijas.

Savstarpējās saskaņošanas procedūra kalpo, lai novērstu nodokḷu konvencijām neatbilstošu aplikšanu ar nodokḷiem, t. i., novērstu dubulto aplikšanu ar nodokliem, novērstu izvairīšanos no nodokḷu maksāšanas, novērstu krāpniecību. MAP uzdevums nav veikt papildu nodokḷu uzrēķinus. Lìdz ar

\footnotetext{
${ }^{6}$ Vogel K. Double Tax Treaties and Their Interpretation. Berkeley Journal of International Law 1986-01. Available at: https://lawcat.berkeley.edu/record/1112555?ln=en [aplūkots 07.01.2020.].

${ }^{7}$ Chetcuti J. Arbitration in International Tax Dispute Resolution. Available at: http://www.inter-lawyer. com/lex-e-scripta/articles/tax-arbitration.htm [aplūkots 08.01.2020.].

8 Ibid.

${ }^{9}$ b.a. Organisation for European Economic Co-operation. Available at: https://www.oecd.org/general/ organisationforeuropeaneconomicco-operation.htm [aplūkots 09.01.2020.].

${ }^{10}$ b.a. Latvijas Republikas konvenciju par nodokḷu dubultās uzlikšanas un nodokḷu nemaksāšanas novēršanu statuss. Pieejams: https://www.fm.gov.lv/lv/sadalas/nodoklu_politika/nodoklu_konvencijas/ divpusejo_konvenciju_statuss/[aplūkots 10.01.2020.].

11 OECD. Model Tax Convention on Income and on Capital: Condensed Version 2017, OECD Publishing. Available at: http://dx.doi.org/10.1787/mtc_cond-2017-en 9.p [aplūkots 11.01.2020.].
} 
to MAP kalpo kā pārnacionāls rīks tiesiskās noteiktības principa veicināšanai starp divām valstīm (Latvijā daudzpusējais MAP starp vairākām valstīm nav pieejams).

Tiesiskās noteiktības princips ir vispārējais tiesību princips. Satversmes tiesa ir atzinusi vispārējos tiesību principus kā tiesību avotu, vispārējiem tiesību principiem ir augstāks juridiskais spēks nekā rakstītām tiesību normām, izṇemot konstitucionālās normas. ${ }^{12}$ Vispārējie tiesību principi nosaka tiesiskās sistēmas saturu un struktūru, uzliek juridiskus pienākumus un piešķir subjektīvas tiesības. ${ }^{13}$ Tiesiskās noteiktības princips uzliek valstij pienākumu nodrošināt tiesisko attiecību noteiktību un stabilitāti, kā arī ievērot tiesiskās paḷāvības principu, lai veicinātu indivīda uzticību valstij un likumam. ${ }^{14}$ Tiesiskās noteiktības princips noteic, ka iestādei ir jāseko tās iedibinātajai praksei un jādarbojas konsekventi tādā veidā, kā tā ir darbojusies līdz šim līdzīgās situācijās, tādējādi sargājot privātpersonām radīto uzticību valstij un tiesībām. ${ }^{15}$ Iestādei jāseko tās iedibinātai praksei neatkarīgi ne no tā, vai konkrētā privātpersona vispār zina par šādas iestādes prakses esamību, ne arī no tā, vai tā ir bijusi publicēta, jo iestādei jānodrošina vienlīdzīga attieksme gan pret tām privātpersonām, kuras ir uzzinājušas par iestādes praksi, gan pret tām privātpersonām, kuras par to nemaz nav zinājušas. ${ }^{16}$

MAP procesā pašreiz Latvijā, vērtējot no nodokḷu maksātāja pozīcijas, ir tiesiskās noteiktības problēmas, process ir maz lietots, pieejamā informācija par procesu nerada pārliecību, ka procesa laikā, interpretējot nodokḷu konvencijas, tiktu pilnvērtīgi novērsta dubultā aplikšana ar nodokḷiem. Pašreiz Latvijā apjomīgākā dubultā aplikšana ar nodokḷiem izcel̦as valstu veikto transfertcenu auditu rezultātā. Piemēram, vienā valstī tiek veikts nodokḷa uzrēḳins par uzņēmuma peḷnu no starptautiskajiem darījumiem ar tā saistīto uzṇēmumu, bet otrā valstī ar kredīta metodi vai atbrīvojuma metodi netiek samazināts nodokḷu maksājums par korigèto vietējo peḷnu saistìtajam uzṇēmumam. Lìdz ar to faktiski starptautisko uzṇēmumu grupa samaksā UIEN par vienu un to pašu ienākumu divās valstīs. To dēvē par ekonomisko dubulto aplikšanu ar nodokliem.

Dubulto aplikšanu ar nodokḷiem MAP procedūrā var novērst ja:

a) valsts, kas veic auditu, atkāpjas no savas pozīcijas (rezultātā valsts, kas veic auditu, zaudē iekasēto nodokli, valsts, kurā neveica auditu, nosargā savu nodokli);

b) otra valsts, kurā neveica auditu, piekāpjas valstij, kas veica auditu (valsts, kas veic auditu, nosargā savu nodokli, valsts, kas neveica auditu, zaudē iekasēto nodokli);

12 Ziemele I. Satversmes tiesas loma konstitucionālo principu aizsardzībā un piemērošanā. Jurista Vārds, 21.11.2017., Nr. 48 (1002), 21. lpp. [aplūkots 20.03.2020.].

13 Rezevska D. Referāta "Tiesiskās drošības un paḷāvības princips - būtiski tiesiskas valsts principa elementi” tēzes. Pieejams: http://blogi.lu.lv/tzpi/files/2016/09/REZEVSKA_D_TEZEs.pdf [aplūkots 20.03.2020.].

14 Satversmes tiesas 25.10.2004. spriedums lietā Nr. 2004-03-01 “Par likuma "Par valsts pensijām" 30. panta piektās un sestās daḷas atbilstību Latvijas Republikas Satversmes 1. un 91. pantam”, 9.2. punkts. Latvijas Vēstnesis, 26.10.2004., Nr. 169.

15 Rezevska D. Referāta "Tiesiskās drošības un paḷāvības princips - būtiski tiesiskas valsts principa elementi” tēzes. Pieejams: http://blogi.lu.lv/tzpi/files/2016/09/REZEVSKA_D_TEZEs.pdf [aplūkots 20.03.2020.].

16 Ibid. 
c) vienošanās rezultātā abas valstis vienojas, kādā apmērā katra zaudē iekasēto nodokli.

Procedūras rezultātā dubultā aplikšana ar nodokli ne vienmēr tiek novērsta, ja kompetentās iestādes nespēj vienoties par taisnīgu iekasēšanas tiesību sadali, jāṇem vērā, ka MAP procedūra neiejaucas valstu suverenitātē par nodokḷu jautājumu regulēšanu. Procedūrai jāaizsargā nodokḷu maksātāja tiesības tikt apliktam ar nodokḷiem saskaṇā ar nolīgumiem un konvencijām un jānovērš tādu nodokḷu uzlikšanu, kas neatbilst nolīgumiem un konvencijām. Lìdz ar to savstarpējās saskaṇošanas procedūrai nevajadzētu kalpot kā valstu instrumentam nodokḷu ienākumu nosargāšanai, tā ir jāveido kā nodokḷu maksātāju instruments taisnīgas nodokḷu iekasēšanas nodrošināšanai.

OECD vēl joprojām strādā pie MAP pilnveides. Viens no OECD darba kārtības punktiem ir BEPS 14. ziņojuma "strīdu risināšanas efektivizācija"17 papildināšana un tā ieviešana praksē, kas sevī ietver valstu īstenoto MAP pārbaudes, rekomendāciju izvirzī̌sanu un labākās prakses piemēru ieteikšanu, lai saskaņotu MAP procedūras minimālos standartus, kas padarītu MAP skaidrāku un pieejamāku nodokḷu maksātājiem globālā līmenī. BEPS 14. ziṇojums "strīdu risināšanas efektivizācija” tiecas saskaņot valstu MAP režìmus ar OECD nodokḷu konvenciju modeli, OECD FTA MAP foruma dalibvalstu saskan,otajiem minimālajiem standartiem un OECD FTA MAP foruma saskaņoto labāko praksi. Jāatzīst, ka nedz standarti, labākā prakse un nodokḷu konvencijas modelis nav juridiski saistoši līdz brīdim, kamēr to atziņas tiek ieviestas valstu noslēgtajās nodokḷu konvencijās un citos normatīvajos aktos.

\section{Globālā līmeņa tiesiskās noteiktības problēmas MAP procedūrā}

Autora ieskatā tiesiskās noteiktības principa problēmas jāapskata divās dažādās MAP procedūras stadijās: MAP uzsākšanas stadijā un procedūras norises stadijā. MAP uzsākšanas stadijas un procedūras norises problēmas ir jāatrisina, jo pašreizējā situācijā MAP procedūras ietvaros no sākuma līdz galam nodokḷu maksātājs ir kā nolaupīts ḳīlnieks. Šādu apgalvojumu var izteikt, analizējot MAP regulējošo normativvo aktu liberālo pieeju termiņiem un ievērojot to, ka nodokḷu maksātājs visas procedūras laikā cieš no dubultās aplikšanas ar nodokḷiem. Tomēr pēdējos gados OECD un ES darbības rezultātā MAP piemēro arvien biežāk. ${ }^{18}$ Dubultā uzṇēmumu ienākuma aplikšana ar nodokḷiem var būt paralizējoša pat starptautisko uzṇēmumu darbībai. Saskaṇā ar OECD MAP statistiku MAP procedūras transfertcenu lietās tiek risinātas ļoti ilgi, piemēram, 2018. gadā pabeigtās strīdu jautājumu lietas vidēji tika risinātas 33 mēnešus. ${ }^{19}$ Jāṇem vērā, ka statistikā nav iekḷauts laiks, kas patērēts līdz strīdu jautājumu lietas ierosināšanai. Procedūras uzsākšanas laiku labākajā gadījumā var sākt

17 OECD, Making Dispute Resolution Mechanisms More Effective, Action 14 - 2015 Final Report, OECD/ G20 Base Erosion and Profit Shifting Project, OECD Publishing, Paris, 2015. Available at: https:// doi.org/10.1787/9789264241633-en. [aplūkots 12.01.2020.].

${ }_{18}$ Morris E. From best endeavours to binding arbitration: Eliminating double taxation. Available at: https://www.internationaltaxreview.com/article/b1f7mxp48msjv4/from-best-endeavours-to-bindingarbitration-eliminating-double-taxation [aplūkots 15.01.2020.].

19 OECD. Mutual Agreement Procedure Statistics for 2018. Available at: https://www.oecd.org/tax/ dispute/mutual-agreement-procedure-statistics.htm [aplūkots 13.01.2020.]. 
skaitīt tikai nedēl̦u no paziņojuma par MAP pieteikuma saṇemšanu, bet sliktākajā gadījumā MAP var neuzsākt arī gadiem. ${ }^{20}$ Bieži vien nodokḷu maksātāja iesniegumu nepieņem pirmajā reizē un pieprasa papildu informāciju, procesu neuzsāk, kamēr kompetentā iestāde nav saṇēmusi tai nepieciešamo informāciju. Tās kompetentās iestādes, kas atrodas Eiropas Savienībā, saṇemot ES rezidenta MAP pieteikumu, jaunās direktīvas ietvaros tās akceptē vai noraida sešu mēnešu laikā pēc tā saṇemšanas, tomēr arī šajā gadījumā procedūras uzsākšanas process var ievilkties, jo kompetentās iestādes var vairākkārtīgi pieprasīt papildu informāciju. Pēc prasītās informācijas iesniegšanas nodokḷu maksātājs var atkal gaidìt līdz pat sešiem mēnešiem, līdz MAP, iespējams, tiks uzsākta. Savstarpējās procedūras uzsākšanas un pabeigšanas novilcināšanu, administratīvo šķērš̌lu izvirzī̌̌anu var vērtēt kā atteikšanos nodrošināt taisnīgumu. ES rezidentiem ir priekšrocības, jo jaunajā direktīvā ir norādīti dokumenti, kas nodokḷu maksātājam ir jāiesniedz. Tomēr direktīva neizskauž tiesisko nenoteiktību, pēc iesniegtā lūguma pieņemšanas nodokḷu maksātājam procedūras ietvaros līdz tās iznākumam vairs nav lomas, kompetentās iestādes tam var nesniegt informāciju par procedūras norisi un sagaidāmo rezultātu, lìdz ar to tam ir jāgaida, līdz kompetentās iestādes vienosies par MAP atrisinājumu, kas Eiropas Savienībā var ilgt pat trīs gadus, kopš kompetentā iestāde saṇēmusi visu nepieciešamo informāciju no nodokḷu maksātāja. Veicot MAP ar valstīm ārpus ES, lielākajā dal̦ā nodokḷu konvencijās nav noteikts lietu izskatīšanas laiks, OECD FTA MAP foruma juridiski nesaistošajos minimālajos standartos, nešķirojot MAP lietu kategorijas, noteikts, ka MAP strīdu jautājumu lietas jācenšas atrisināt divu gadu laikā, ievērojot transfertcenu MAP strīdu jautājumu lietu sarežgítību (transfertcenu dokumentācijas analīzes laiks, salīdzinošās atlases izveides laiks, pozīciju papīru sagatavošanas laiks, informācijas apmaiṇas laiks). Transfertcenu kategoriju lietu vidējā sarežgítības pakāpe ir augstāka par visām pārējām lietām, tāpēc arī nelogiski uz visām MAP kategorijām attiecināt vienu un to pašu termiṇu. Tikai nedaudzās nodokḷu konvencijās ir noteikts MAP procedūras ilgums, piemēram, Latvijas Republikas nodokḷu konvencijā ar Japānu ir norādīts divu gadu termiņšs, kura laikā, nepanākot vienošanos, ir jāuzsāk ne mazāk laikietilpīgā arbitrāžas procedūra.

Ievērojot iepriekš minētos termiņus, paliek nemainīgs fakts, ka nodokḷu maksātāja līdzekḷi, ko tas varētu izmantot savai saimnieciskajai darbỉbai, ir samazināti par dubultā nodokḷa apjomu, turklāt, pat sasniedzot nodokḷu maksātājam labvēlīgu rezultātu MAP procedūrā, tam rodas papildu kaitējums par neizmantoto kapitālu (kuru neviens tam nekad neatmaksās, ņemot vērā to, ka valstis vienojas par MAP rezultātu, nevis atzīst nepareizu nodokḷu iekasēšanu).

Tiesiskās noteiktības problēmas izpaužas arī, vērtējot iespējamos MAP rezultātus. Jāanalizē konkrētās noslēgtās nodokḷu konvencijas izpratne par to, kas ir konvencijas tvērumā ietilpstošais nodoklis. Latvijas noslēgtās nodokḷu konvencijas tvērumā ietilpst tikai iedzìvotāju ienākuma nodoklis un uzņēmumu ienākuma nodoklis. Tā ir nodokḷu maksātājam neizdevīga pieeja, kur MAP procedūras rezultātā, koriǵējot apliekamo ienākumu valstī, var proporcionāli

${ }^{20}$ OECD, BEPS Action 14 on More Effective Dispute Resolution Mechanisms - Peer Review Documents, OECD/G20 Base Erosion and Profit Shifting Project, OECD, Paris, 2016. Available at: www.oecd.org/ tax/beps/beps-action-14-on-more-effective-dispute-resolution-mechanisms-peer-review-documents. pdf [aplūkots 14.01.2020.]. 
nekorig̣ēt nokavējuma naudu un soda naudu. Šāda situācija nozīmē, ka uzṇēmumam ir jāveic maksājumi, kas nemaz nebūtu radušies, ja MAP vienošanās rezultāts būtu piemērojams jau dubultās aplikšanas ar nodokḷiem izcelšanās dienā. Taisnīgāka pieeja šajā jomā būtu interpretēt konvencijas noteikumus par labu nodokḷu maksātājam, līdzīgi kā Lielbritānijā. ${ }^{21}$ Lielākā daḷa MAP konvenciju piel̦auj rīcības brīvību, savstarpēji vienojoties par risinājumu jebkuriem sarežğījumiem vai šaubām, kas rodas, interpretējot nodokḷu konvenciju, tajā skaitā arī par to, kas konvencijas ietvarā būtu uzskatāms par nodokli. Nodokḷu maksātājam nav iespēju jebkādi ietekmēt valstu pieṇemtos lēmumus MAP procedūrā, tas tiem var tikai piekrist un nepiekrist. Kompetentās iestādes rīkojas tiesiski, bet ne taisnīgi, vienojoties tikai par dubultās aplikšanas novēršanu, neskatot nokavējuma un soda naudas samazināšanu. Nesamazinot šos maksājumus, noslēdzot vienošanos par dubultās aplikšanas ar nodokḷiem novēršanu, tiek novērsta tikai pamatsummas aplikšana, bet kopumā dubultā aplikšana netiek novērsta, tā tiek tikai mīkstināta. MAP procedūru tiesiskās noteiktības problēmas un to riski liek nodokḷu maksātājiem šo procedūru uztvert kā pēdējo salmiṇu.

\section{Vietējā līmeṇa tiesiskās nenoteiktības problēmas MAP procedūrā}

Kā iepriekš minēts, pret dažādu valstu nodokḷu rezidentiem piemēro MAP pèc atškirīga tiesiskā regulējuma. Eiropas Savienības ietvaros MAP process ir noregulēts ar 2017. gada 14. oktobra direktīvu (ES) 2017/1852 par nodokḷu strīdu izšķiršanas mehānismiem un ar arbitrāžas konvenciju. Šì direktīva un konvencija neattiecas uz MAP procedūrām ar valstīm, kas nav Eiropas Savienībā. Ir panākta līdzīga izpratne par MAP procesuālajiem pamatjautājumiem starp Eiropas Savienības dalībvalstīm. Likuma "Par nodokḷiem un nodevām” XV nodaḷa neveicina tiesisko noteiktību attiecībā uz MAP procedūrām ar valstīm, kas nav Eiropas Savienībā, jo tā ir izmantojama tikai MAP procedūrās ar citām Eiropas Savienības dalībvalstu kompetentajām iestādēm. Uz MAP procedūrām ar pārējām valstīm attiecas tikai tie noteikumi, kas norādīti nodokḷu konvencijās. Konvencijās ietvertie paragrāfi ir diezgan līdzīgi. Visās Latvijas nodokḷu konvencijās ir ietverts vispusīgs paragrāfs par MAP, kas regulē MAP iesniegšanas termiņu, valsti vai valstis, kur iesniegums jāiesniedz, noteikums, ka valstīm jācenšas savstarpēji atrisināt jebkādas problēmas vai šaubas, kas izriet no to nodokḷu konvenciju interpretācijas. Interpretācijai paliek atvērti būtiski punkti - strīdu jautājuma lietas ierosināšanas kritēriji, procesa norise, nodokḷu maksātāja loma, iesniedzamā informācija, ko var sagaidìt kā procedūras iznākumu. MAP procedūrā starp Latviju un valsti ārpus Eiropas Savienības nodokḷu maksātājam nav ne garantijas, ne skaidrības, ka viṇa pieteikums tiks pieṇemts Latvijā, ja salīdzina ar līdzīgas kvalitātes pieteikumu, kas iesniegts MAP procedūrā, kura regulēta pēc Eiropas Savienības tiesību normām. Vienīgais, kritērijs, ar ko var rēḳināties ārvalsts nodokḷu maksātājs, ir nodokḷu konvencijas 25. panta pirmais teikums, kas 59 Latvijas nodokḷu konvencijās paredz, ka MAP iesniegumu var iesniegt tikai vienai valstij, savukārt divās konvencijās (ar Japānu

${ }^{21}$ b.a. Mutual Agreement Procedure (MAP). Available at: https://www.gov.uk/government/publications/ statement-of-practice-1-2018/statement-of-practice-1-2018 [aplūkots 15.01.2020.]. 
un Amerikas Savienotajām Valstīm) paredz, ka iesniegumu var iesniegt abām iesaistītajām valstīm vienlaicīgi.

Pēc tiesiskās noteiktības principa attiecībā uz visiem nodokḷu maksātājiem, kas ir līdzīgos apstākḷos, ir jāattiecina vienāds regulējums. Arī tiem nodokḷu maksātājiem, kas ar nodokḷiem dubulti aplikti gan Latvijā, gan citā valstī, kas atrodas ārpus Eiropas Savienības, ir jānodrošina tiesiskā noteiktība. Pirmais solis tiesiskās noteiktības veicināšanai izpaustos, papildinot likumu "Par nodokliiem un nodevām” ar līdzīgiem noteikumiem, kas izklāstīti tā XV nodaḷā, bet attiektos uz tām MAP strīdu jautājumu lietām ar valstīm, kas nav Eiropas Savienībā.

Līdz ar to kompetentajai iestādei nevajadzēs interpretēt strīdu jautājumu lietas ierosināšanas kritērijus, kas apgrūtina MAP procedūras uzsākšanu.

\section{Tiesiskās noteiktības problēmas, kas saistītas ar strīdu jautājuma lietas rezultātu}

Lai gan MAP process ir neskaidrību pilns, pēc tā būtības tas ir svarīgs rīks transfertcenu tiesiskās noteiktības veicināšanā. Ne velti OECD transfertcenu vadlīnijās atgādināts, ka transfertcenas nav eksaktās zinātnes. ${ }^{22}$ Transfertcenās gandrīz nekad nav vienas universāli atzìtas precīzas atbildes. Katrai valstij ir savi nodokḷu likumi, sava pieeja pareizai transfertcenu noteikšanai, MAP procedūra kalpo kā šo pieeju savstarpēja saskaņošana, lai valstis varētu vienoties par konkrētu, abpusēji pieņemamu risinājumu par labu nodokḷu maksātājam. Objektīvai pieejai MAP procesam traucē pārāk stingra pieturēšanās pie audita pozīcijām, procedūrai deleǵējot auditorus, kas paši izstrādājuši MAP procedūras ietvaros saskan,ojamo pozīciju. ${ }^{23}$ MAP procedūras ietvaros valstis iepazīstas ar jauniem faktiem, kas nebija pieejami audita veikšanas laikā, šie jaunie fakti procedūras ietvaros jāizmanto, lai nonāktu pie kopīga risinājuma.

Tiesisko noteiktību neveicina fakts, ka, ņemot vērā MAP specifiku, tā ietvaros valstis, lai pamatotu savu pozīciju, var izmantot tikai sev zināmus slepenos salīdzināmos datus (tos izmanto, lai aprēḳinātu atbilstošo darījumu tirgus vērtību), par kuriem dati ir iegūti no citiem nepieejamiem, nepubliskiem avotiem. Analog̣iskās situācijās, veicot auditu, šos datus Latvijā nedrīkst izmantot, lai pamatotu kompetentās iestādes aprēḳināto atbilstošo uzṇēmumu darījumu tirgus vērtību, jo šos datus nedrīkst izpaust datu aizsardzības iemeslu dēḷ, tāpat šos datus arī nevar izmantot, lai pamatotu procedūras rezultātu automātisku izmantošanu attiecībā uz nākamajiem gadiem, pēc procedūras noslēgšanas.

Tiesisko noteiktību neveicina fakts, ka virknē nodokḷu konvenciju noteikts, ka kompetentajām iestādēm ir tikai jātiecas nonākt pie risinājuma savstarpējo saskaņošanas procedūru lietās. Eiropas Savienībā šì problēma tiek risināta, direktīvā ieviešot arbitrāžas procedūru, kur abu kompetento iestāžu deleǵètie pārstāvji kopā ar neatkarīgiem pārstāvjiem izveido komisiju, kas pēc MAP

22 OECD. OECD Transfer Pricing Guidelines for Multinational Enterprises and Tax Administrations 2017, OECD Publishing, Paris. Available at: http://dx.doi.org/10.1787/tpg-2017-en 37.p.3 [aplūkots 18.01.2020.].

23 OECD, Making Dispute Resolution Mechanisms More Effective, Action 14 - 2015 Final Report, OECD/ G20 Base Erosion and Profit Shifting Project, OECD Publishing, Paris, 2015. Available at: https:// doi.org/10.1787/9789264241633-en. 22.p [aplūkots 12.01.2020.]. 
procedūras sarunu vešanas izgāšanās risina jaunu, līdzīgu procesu līdzīgā kārtībā kā savstarpējās saskaņošanas procedūra. Bet jau ar obligātu pienākumu nonākt pie risinājuma. ${ }^{24}$ Pētot valstu MAP statistiku un iztaujājot MAP speciālistus, var secināt, ka pat nodokḷu administrāciju pārstāvji zaudē pārliecību par iespējamo strīdu jautājuma lietas rezultātu, tādējādi fakts vien, ka tuvojas arbitrāžas procedūras noteiktais termiņš, mudina kompetentās iestādes vienoties, jo arbitrāžas komisiju lēmumi var krietni atšḳirties no tās vienošanās, pie kādas tās būtu savstarpēji nonākušas. Paši nodokḷu maksātāji pauž, ka kompetento iestāžu MAP komandas, vienojoties ar otro valsti, pien,emot lēmumus, ṇem vērā arī citu nesaistītu lietu progresu ar šo valsti, līdz ar to viens īpaši labvēlīgs lēmums vienam uzṇēmumam var izraisìt nelabvēlīgu lēmumu otram uznēèmumam. ${ }^{25}$

\section{Secinājumi}

1. Savstarpējās procedūras uzsākšanas un pabeigšanas novilcināšanu, administratīvo šḳēršl lu izvirzīšanu var vērtēt kā atteikšanos nodrošināt taisnīgumu. Balstoties uz pašreizējo MAP tiesisko regulējumu, Latvijas kompetentā iestāde MAP procedūras ietvaros saistībā ar uzṇēmumu ienākumiem, kas gūti ES pirms 2018. gada 1. janvāra un visās pārējās lietās, neaprobežojoties ar jebkādu termiṇu ar trešajām valstīm, var izvirzìt jebkādus administratīvus šḳēršlus.

2. Pèc pašreizējā Latvijas normatīvo aktu regulējuma MAP procedūras nekliedē tiesisko nenoteiktību, tās ir nepopulārs rīks, jo procesa norise ir nodokḷu maksātājam nesaprotama un procedūras rezultāts ne vienmēr novērš ar nodokḷiem apliekamā objekta dubulto aplikšanu ar nodokḷiem. Turklāt procedūra neaptver nokavējuma naudas, soda naudas un procentu maksājumus.

3. Procedūras ietvaros jāievieš ierobežots saudzējošais režīms attiecībā uz nodokḷu maksātājiem, kas apturētu nodokḷu maksātāja nokavējuma naudas, soda naudas un procentu maksājumu pieaugumu. Nodokḷu maksātāja lïdzekḷi, ko tas varētu izmantot savai saimnieciskajai darbībai, ir samazināti par dubultā nodokḷa apjomu no dubultās aplikšanas ar nodokḷiem dienas līdz pat MAP vai arbitrāžas procedūras nobeigumam. Pat sasniedzot nodokḷu maksātājam pēc iespējas labvēlīgāku rezultātu MAP procedūrā, pilnībā novēršot dubulto aplikšanu, tam rodas papildu kaitējums par neizmantoto kapitālu (kuru neviens tam nekad neatmaksās, n,emot vērā to, ka valstis vienojas par MAP rezultātu, nevis atzīst nepareizu iekasēšanu).

\footnotetext{
24 “Par nodokliem un nodevām”: LV likums. Latvijas Vēstnesis, 18.02.1995., Nr. 26, 130. panta pirmā daḷa.

25 OECD. Model Tax Convention on Income and on Capital: Condensed Version 2017, OECD Publishing. Available at: http://dx.doi.org/10.1787/mtc_cond-2017-en p.334 [aplūkots 11.01.2020.].
} 